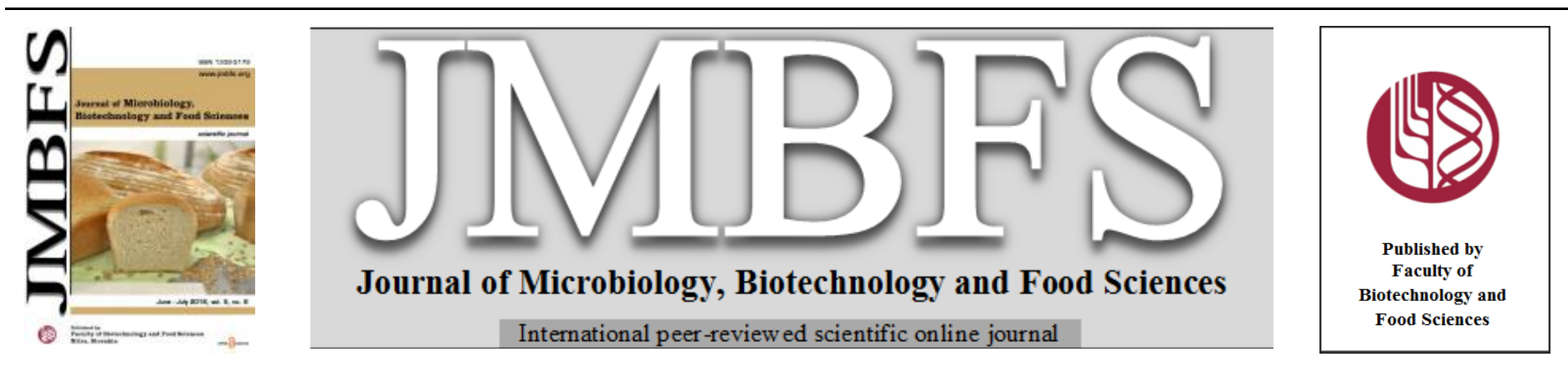

\title{
IMPROVEMENT OF BORASSUS AKEASSII WINES QUALITY BY CONTROLLED FERMENTATION USING SACCHAROMYCES CEREVISIAE STRAINS
}

\author{
TAPSOBA François ${ }^{1 *}$, SAVADOGO Aly ${ }^{1,2}$, ZONGO Cheikna ${ }^{3}$, TRAORÉ Sababenedyo Alfred ${ }^{1,2,3}$
}

\section{Address(es):}

${ }^{1}$ Laboratory of Microbiology and Biotechnology, Research Center in Biological, Food and Nutrition Sciences (CRSBAN), Department of Biochemistry and Microbiology, University of Ouagadougou, Burkina Faso.

${ }^{2}$ Laboratory of Food Technology, Department of Biochemistry and Microbiology, University of Ouagadougou, Burkina Faso.

${ }^{3}$ Laboratory of Clinical Biochemistry and pharmacology, Department of Biochemistry and Microbiology, University of Ouagadougou, Burkina Faso.

*Corresponding author: tapsobaf@gmail.com, francois.tapsoba@univ-ouaga.bf

doi: 10.15414/jmbfs.2016.5.6.589-592

\section{ARTICLE INFO}

Received 24. 3. 2015

Revised 12. 2. 2016

Accepted 18. 2. 2016

Published 1. 6. 2016

Regular article

open ${ }_{\text {ACCESS }}$

\begin{abstract}
Palm wine produced traditionally and consumed by many people around the world and specifically in Burkina Faso posed health risks because of questionable quality of wine produced by mix culture fermentation and the use of antiseptics for the stabilization. In order to improve its quality, Saccharomyces cerevisiae strains isolated from Borassus akeassii wines and identified by amplification and RFLP analysis of the 5-8S-ITS region were used for in vitro fermentation of unfermented palm sap. The physicochemical characteristics of the sap were measured before and after fermentation process by High-Performance Liquid Chromatography (HPLC) and the microbiological quality were also performed. HPLC analysis showed that glucose and fructose concentration in palm sap were 37.0 and $27.6 \mathrm{~g} / \mathrm{L}$ respectively, ethanol content was ranged between 2.76 and $5.31 \%(\mathrm{~g} / \mathrm{mL})$ for controlled fermentation and $2.20 \%(\mathrm{~g} / \mathrm{mL})$ for spontaneous fermentation. Lactic and acetic acids were ranged between 0.1 and $0.3 \mathrm{~g} / \mathrm{L}$ and 1.5 and $1.6 \mathrm{~g} / \mathrm{L}$ for controlled fermentation versus 2.5 and $3.1 \mathrm{~g} / \mathrm{L}$ and the spontaneous fermentation respectively. Coliforms and Staphylococcus aureus were detected only in the unfermented palm sap and the wine fermented spontaneously.

Principal component analysis showed a good separation between spontaneous and controlled fermentation. Sterilization and controlled fermentation of the unfermented sap with palm wine Saccharomyces cerevisiae strains led to the improvement of palm wine quality.
\end{abstract}

\section{INTRODUCTION}

Palm wine is an alcoholic beverage from the sap of various species of palm tree such as Palmyra and coconut palm (Adeleke and Abiodun, 2010). It is a sweet alcoholic beverage widespread in African, American and Asian tropical regions and which is obtained by spontaneous fermentation of sap tapped from palm trees such as Elaeis guineensis , Raphia hookeri, Raphia vinifera (Ezeronye and Legras, 2005) and Borassus akeassii Bayton (Bayton et al., 2006 ; Bayton and Ouédraogo, 2009). Palm wine contains 300 calories/L, 0.5-2.0 g of proteins, considerable of vitamins, a major component of which is vitamin $\mathrm{A}, \mathrm{C}$ and $\mathrm{K}$ helps consumers eye sight, protects and improves the eye sight (SantiagoUrbina and Ruíz-Terán, 2014). Many components of palm wine have been found previously in conventional wines. This wine is colorless and very sugary (Obahiagbon and Osagie, 2007) until sugars are fermented into alcohol then organic acids spontaneously. According to producers and consumers, palm wine obtained by mix culture (spontaneous) fermentation, gets inconsumable after 3 days (Ouoba et al., 2012). Natural uncontrolled fermenting process led to unstableness and easy spoilage of this product quality (Ngoc et al., 2014). This beverage produced traditionally is unstable, therefore exposed to alteration if fermentation is not controlled. The acidification and instability of palm wine during its fermentation need to be controlled in order to ensure its quality. Different antiseptics such as sorbic acid, diethylpyrocarbonate (DEPC) and sodium metabisulfite have been already used for stabilisation of palm wine (Okafor, 1975 a). Even though use of these antiseptics would be the efficient means for the stabilization of palm wine, they can pose health risks. In a former work, coliforms and Staphylococcus aureus were detected in natural palm wine (Tapsoba et al., 2011; 2014). According Olawale et al. (2010), sterilization and use of purified Saccharomyces cerevisiae in fermentation of palm sap could confer a more quality and hygienic palm wine. Because of questionable quality of palm wine produced by mix culture fermentation and the use of antiseptics for the stabilization towards the world and specifically in Burkina Faso, we proposed an improvement of this beverage quality by controlled fermentation of unfermented sap with selected strains of Saccharomyces cerevisiae isolated from palm wine. It has been to use active $S$. cerevisiae strains isolated from Borassus akeassii palm wine for fermentation of the unfermented sap, evaluate the microbiological and biochemical quality of palm wine produced secondly and to compare controlled fermentation and spontaneous.

\section{MATERIAL AND METHODS}

\section{Sampling of palm crude sap}

Palm crude sap of the same B. akeassii species was purchased in South-West of Burkina Faso where palm wine is largely tapped and very consumed. Two samples of $1 \mathrm{~L}$ of fresh palm sap were transferred in sterile plastic containers which were immediately immersed in an isothermal box, and brought to the laboratory and maintained at $4^{\circ} \mathrm{C}$ before the analysis.

Before fermentation, $10 \mathrm{~mL}$ of the unfermented palm sap were used for microbiological analysis and $15 \mathrm{~mL}$ were filtered and stored at $-20^{\circ} \mathrm{C}$ for further analysis

\section{Palm wine fermentation process}

\section{Preparation of the inoculums for fermentation}

We used Saccharomyces cerevisiae strains YBPW7, YBPW13 and YBPW25 isolated from Borassus akeassii wines and identified by amplification and RFLP analysis of the 5-8S-ITS region (Esteve-Zarzoso et al., 1999). Each strain was overnight grown aerobically in shake $10 \mathrm{~mL}$ flasks at $30{ }^{\circ} \mathrm{C}$ in YPD medium (1 $\%$ yeast extract, $2 \%$ peptone and $2 \%$ glucose).

\section{Fermentation process assays}

The unfermented palm sap was subjected to flowing vapor sterilization as method described by Clément (2012). The fermentation assays were carried out using Saccharomyces cerevisiae strains YBPW7, YBPW13 and YBPW25 isolated from palm wines to inoculate $250 \mathrm{~mL}$ palm sap collected. The Overnight culture each of strain was used to inoculate $250 \mathrm{~mL}$ of sterilized Borassus akeassii crude 
sap at a density of $10^{6}$ cells / mL. Spontaneous (Mix culture) fermentation was at the same time carried out with the endogenous microorganisms (natural microflora). The experiments were performed at $30^{\circ} \mathrm{C}$ for 72 hours.

Palm wines produced were designed CF7, CF13, CF25 and SP respectively. Sterile samples were collected at 24 hours time intervals for further analysis.

Wine was filtered using cheese cloth as method described by Kumar $\boldsymbol{e t}$ al. (2012) and stored at $4^{\circ} \mathrm{C}$. Then $10 \mathrm{~mL}$ were used for microbiological analysis and $15 \mathrm{~mL}$ were stored at $-20^{\circ} \mathrm{C}$ for analysis of physico-chemical parameters Glucides, organic acids, glycerol and ethanol were measured by HPLC in the supernatant. The $\mathrm{pH}$ was also measured using a $\mathrm{pH}$-meter (WTW 82362) at $25^{\circ}$ C.

\section{Biochemical and microbiological analyses of palm wines}

Sugars, ethanol and organic acids analyses by High-Performance Liquid Chromatography (HPLC)

Glucose, ethanol, glycerol and organic acids in palm wines were determined by High-Performance Liquid Chromatography (HPLC-1 Agilent 1260) equipped of a degasser G132A, a quaternary pump G1311 A, a passor of samples G131 A, a furnace G131 A, a detector UV (G131A) to the variable wavelength, a refractometer G1382 A and a column Phenomenex-Rezex ROA-Organics Acid $\mathrm{H}^{+}$(Size $300 \times 7.8 \mathrm{~mm}$ ). For analysis, column effluents were monitored by an UV detector (G131A) set at $210 \mathrm{~nm}$ and a refractometer (G1382A). The mobile phase $\left(0.0005 \mathrm{~N} \mathrm{H}_{2} \mathrm{SO}_{4}\right)$ filtered through a $0.2 \mu \mathrm{m}$ Millipore membrane filter was used at a low rate of $0.6 \mathrm{ml} / \mathrm{min}$ and $25 \mu \mathrm{l}$ of the prepared sample were automatically injected.

The detection of targeted compounds was performed by refractometry for glucose, fructose, ethanol, glycerol and succinate and by UV spectrophotometry at a wavelength set at $210 \mathrm{~nm}$ for pyruvate and acetate.

\section{Analysis of microbiological quality of produced palm wines}

In order to control the quality of palm wine produced, coliforms bacteria and Staphylococcus aureus counts were performed (Norme ISO 7218, 2007). Ten (10) $\mathrm{mL}$ of each sample were mixed with $90 \mathrm{~mL}$ of sterile peptone solution. Serial dilution was performed with the sterile peptone solution and $100 \mu \mathrm{L}$ of decimal dilutions were plated in duplicate on Petri dishes. Chapman's Agar medium (Sigma Aldrich, USA) were used for Staphylococcus aureus counts and Violet Red Bile Agar (VRBL) (Biokar, France) for coliforms bacteria. Plates were incubated for 48 hours at $37 \pm 2^{\circ} \mathrm{C}$ Staphylococcus aureus counts and VRBL plates that were incubated at $30 \pm 2^{\circ} \mathrm{C}$ for total coliforms and $44 \pm 2^{\circ} \mathrm{C}$ for thermotolerant coliforms for 48 hours. Counts were expressed as colony forming units per $\mathrm{mL}(\mathrm{cfu} / \mathrm{mL})$.

\section{Principal Component Analysis (PCA) of different palm wines}

The comparison of different process was performed by Principal Component Analysis using the package FactoMineR of Rcommander of R 3.2.3.

\section{Data analysis}

Data analyses were performed with $\mathrm{R}$ 3.2.3. Data obtained were subjected to an analysis of variance (ANOVA) using the Fisher's least significant difference (LSD) test to determine significant differences between each sample (wine or sample) $(\mathrm{P} \leq 0.05)$. Principal Component Analysis (PCA) was performed to compare the different types of fermentation by using the package FactoMineR of Rcommander.

\section{RESULTS AND DISCUSSION}

Strains used in this study were YBPW7, YBPW13 and YBPW25, isolated from Borassus akeassii wine. As presented in table 1, strains were identified as $S$ cerevisiae species by amplification and RFLP analysis of the 5-8S-ITS region (Esteve-Zarzoso et al., 1999).

Table 1 Size (bp) of the PCR products and the restriction fragments

\begin{tabular}{lcccc}
\hline \multirow{2}{*}{ Strains } & \multirow{2}{*}{$\begin{array}{c}\text { Fragments size } \\
(\mathbf{p b})\end{array}$} & \multicolumn{2}{c}{ Restricted fragments size (pb) } & \multirow{2}{*}{ Identification } \\
\cline { 3 - 5 } & 880 & Hae III & Hinf I & S. cerevisiae \\
\hline YBPW7 & 850 & $140-360$ & $120-180-220-300$ & S. cerevisiae \\
\hline YBPW13 & 850 & $140-380$ & $120-180-220-300$ & S. cerevisiae \\
\hline YBPW25 & & $140-380$ & $120-180-220-300$ & \\
\hline
\end{tabular}

Many authors reported that $S$. cerevisiae was the species as responsible for the fermentation and aroma of the wine (Amoa-Awua et al,. 2007; Stringini $\boldsymbol{e t}$ al., 2009; Ouoba et al., 2012).

The kinetics of fermentation of palm sap by $S$. cerevisiae was presented in figure 1 .

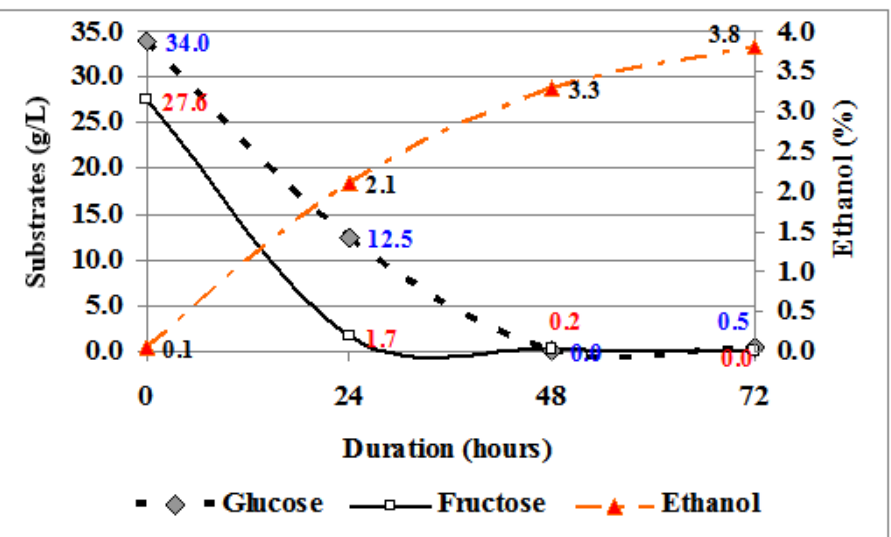

a. Controlled fermentation with Saccharomyces cerevisiae strains

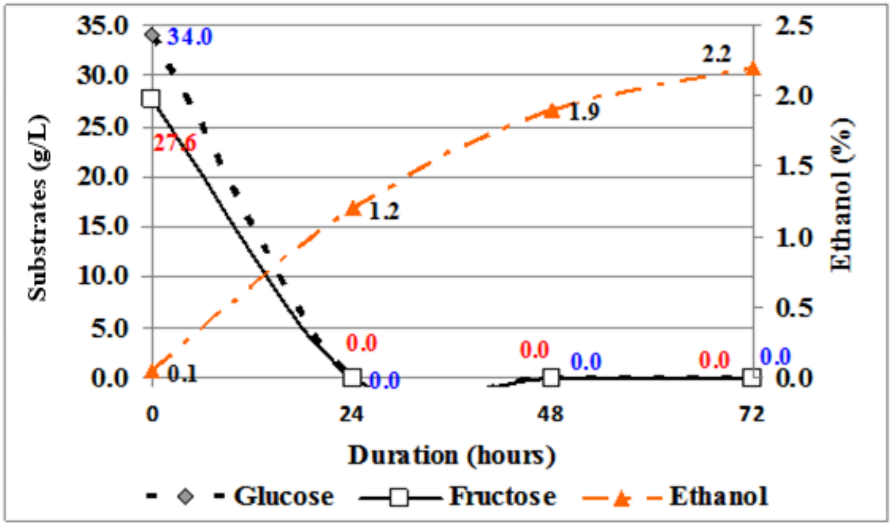

b. Mix culture fermenation of Borassus akeassii sap by endegenous microorganisms

Figure 1 Kinetics of mix culture and controlled fermentation of Borassus akeassii palm wine

Substrates (glucose and fructose) detected in palm sap were consumed completely at 24 hours in the spontaneous (mix culture) fermentation as presented in figure 1a. According to Opara et $\boldsymbol{a l}$. (2013), four micro-organisms were found to be frequently present during the mixed culture fermentation of palm sap. These micro-organisms in the order of succession are: Yeasts, Micrococcus, Lactic Acid bacteria and Leuconostoc spp.

We have analyzed substrates and metabolites present in palm sap and palm wines and the results are presented in table 2 . 
Table 2 Physico-chemical characteristics of crude sap and wines of Borassus akeassii

\begin{tabular}{|c|c|c|c|c|c|c|c|c|c|c|}
\hline Samples & pH & $\begin{array}{c}\text { Glucose } \\
(\mathrm{g} / \mathrm{L})\end{array}$ & $\begin{array}{c}\text { Fructose } \\
(\mathrm{g} / \mathrm{L})\end{array}$ & $\begin{array}{c}\text { Ethanol } \\
(\%)\end{array}$ & $\begin{array}{c}\text { Glycerol } \\
\text { (g/L) }\end{array}$ & $\begin{array}{c}\text { Succinate } \\
(\mathrm{g} / \mathrm{L})\end{array}$ & Acetate $(\mathrm{g} / \mathrm{L})$ & $\begin{array}{c}\text { Malate } \\
(\mathrm{g} / \mathrm{L})\end{array}$ & Lactate $(\mathrm{g} / \mathrm{L})$ & $\begin{array}{c}\text { Pyruvate } \\
\text { (g/L) }\end{array}$ \\
\hline PWS & 6.5 & 34.0 & 27.6 & 0.05 & 0.10 & 0.8 & 1.0 & 1.2 & 0.1 & ND \\
\hline SP & 3.5 & 0.50 & 0.0 & 2.20 & 1.50 & 1.1 & 3.1 & 2.0 & 2.5 & 0.1 \\
\hline CF7 & 4.2 & 0.0 & 0.0 & 5.31 & 3.0 & 2.4 & 1.6 & 0.6 & 0.2 & 0.2 \\
\hline $\mathrm{CF} 13$ & 3.9 & 0.0 & 0.0 & 3.34 & 3.0 & 2.5 & 1.5 & 0.6 & 0.3 & 0.5 \\
\hline $\mathrm{CF} 25$ & 4.5 & 0.0 & 0.0 & 2.76 & 2.6 & 2.5 & 1.6 & 0.4 & 0.1 & 0.2 \\
\hline
\end{tabular}

Legend: PWS: Palm wine sap; SP: Spontaneous fermentation; CFX: Controlled fermentation with strain YVPWX; ND: Not detected

Ethanol was also found in all samples that indicating the alcoholic fermentation. Ethanol content was ranged between 2.76 and $5.31 \%$ for controlled fermentation versus $2.20 \%$ for spontaneous fermentation. Glucose and fructose were about $34.0 \mathrm{~g} / \mathrm{L}$ and $27.6 \mathrm{~g} / \mathrm{L}$ respectively but sucrose was not detected in unfermented palm sap. There was an important production of glycerol in the controlled fermentation. Glycerol concentration was ranged between 2.6 and $3.0 \mathrm{~g} / \mathrm{L}$ versus $1.5 \mathrm{~g} / \mathrm{L}$ in spontaneous fermentation process. Glycerol was the major fermentation by-product of Saccharomyces cerevisiae, which indirectly contributes to the sensory character of wine (Yalçin and Özba, 2006).

The comparison of physicochemical characteristics of palm wines shows that the wine produced by mix culture fermentation is more acidic that those obtained by controlled fermentation. It has also been shown that the mix culture fermentation process is acidic as it progresses and there is proliferation of micro-organisms depending on the condition of the medium (Opara et al., 2013). Naknean et al. (2010) reported that when fructose is available in wine and lactic acid bacteria are able to grow, they can produce equimolar amounts of lactic and acetic acids from fructose and this could constitute a serious source of acetic acid in wine.

The results of microbiological quality of palm sap and wine were presented in table 3 .

Table 3 Microbiological characteristics of palm sap and wines of Borassus akeassii

\begin{tabular}{lccc}
\hline Samples & TC $\left(10^{4}\right)$ & FC $\left(10^{2}\right)$ & S. aureus $\left(10^{5}\right)$ \\
\hline PWS & 3.75 & 1.5 & 3.4 \\
\hline SP & 1.75 & 0.75 & 1.5 \\
\hline CF7 & ND & ND & ND \\
\hline CF13 & ND & ND & ND \\
\hline CF25 & ND & ND & ND \\
\hline
\end{tabular}

Legend: PWS: Palm wine sap; SP: Spontaneous fermentation; CFX: Controlled fermentation with strain YBPWX; ND: Not detected; TC: Total coliforms; FC: Thermotolerant coliforms

In the palm wine obtained by mix culture fermentation and the crude sap, we have detected coliforms and Staphylococcus aureus while in the controlled fermentation, they were not detected. The presence of these microorganisms revealed that unfermented palm sap used is collected under unhygienic condition (Olawale et al,. 2010; Tapsoba et al., 2014).

Bacteria and yeasts usually contaminate the juice as it is tapped and there are changes in biochemical composition of the palm wine (Olawale et al., 2010). Normally, palm sap is a raw material to produce palm sugar syrup. Some factors affected the quality of palm sugar syrup such as processing method and quality of palm sap (Phaichamnan et al., 2010).

Naknean et al. (2009) studied the effect of processing method on quality of palm sugar syrup. Flowing vapor sterilization could be important before fermentation of palm sap because the presence of potential endogenous microorganisms is avoided. The microbiological quality of palm sap becomes important to obtain a more quality and hygienic palm wine.

According to Olawale $\boldsymbol{e t}$ al. (2010), the sterilization and the use of purified Saccharomyces in fermentation of palm sap led to a more quality and hygienic palm wine. Of the yeasts responsible for palm wine fermentation, the predominant and best alcoholic fermenter was Saccharomyces cerevisiae (Stringini et al., 2009).

Fermentation processes were compared using principal component analysis (PCA) as presented in figure 2. This analysis showed a good separation between fermentation processes. The PCA gives also an overview of the differences between the mix culture fermentation and controlled fermentation.

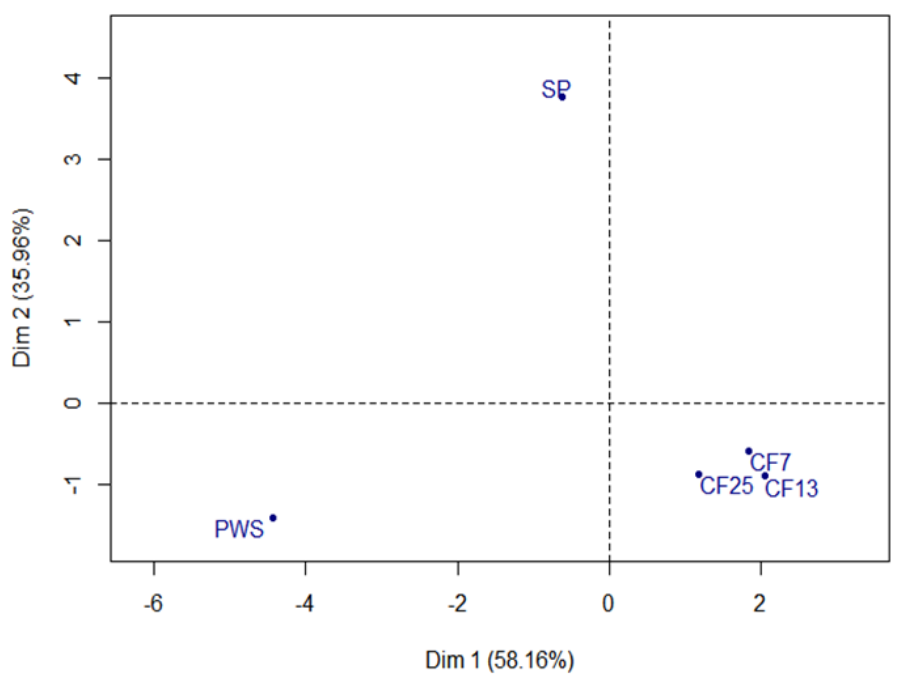

Legend: PWS: Palm wine sap; SP: Mixed culture fermentation; CFX: Controlled fermentation with S. cerevisiae strain X

Figure 2 Principal component analysis of palm wine fermentation

The wines produced by controlled fermentation (CF7; CF13 and CF25) were grouped together in the bottom right of the figure 2 . The wine produced by mix culture fermentation (SP) was at the top of the figure while the unfermented sap (PWS) was shown in the bottom left. This analysis shows that there is a difference between the unfermented sap, the wine produced by mix culture fermentation and the wine obtained by controlled fermentation.

Figure 3 provides the flow chart for controlled fermentation for improved palm wine. Indeed, this diagram provides a wine, different of the wine obtained by mix culture fermentation. It enables the improvement of microbiological and physicochemical quality of palm wine.

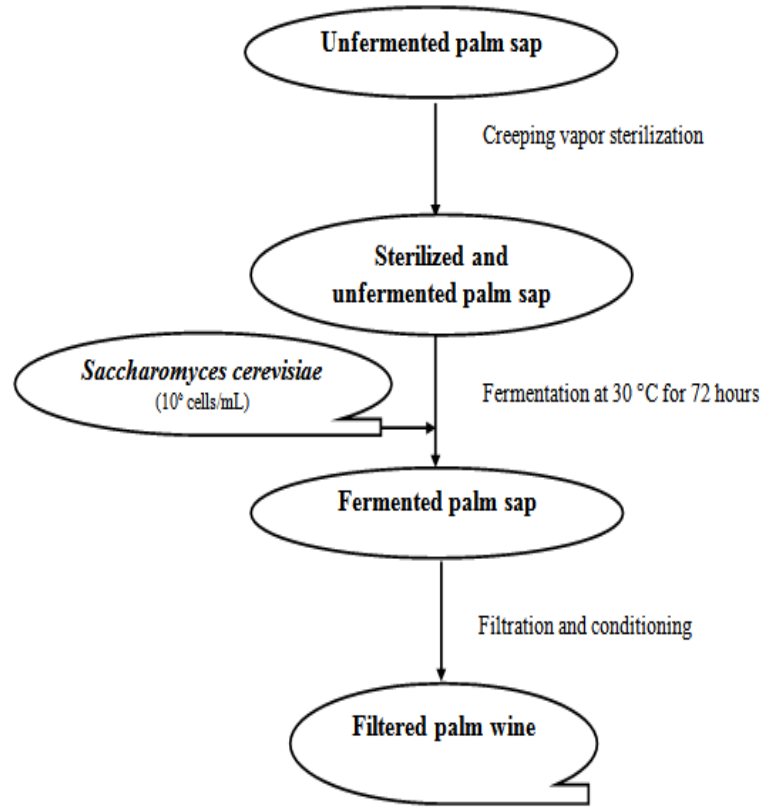

Figure 3 Flow chart (diagram) for controlled fermentation of palm wine 
Flowing (Creeping) vapor sterilization eliminates undesirable microorganisms that could contaminate raw sap during its extraction process. According to the care applied in the collection of the crude sap, a first hypothesis on the presence of potential endogenous microorganisms in the sap was emitted (Ben Thabet $\boldsymbol{e t}$ al. 2010).

\section{CONCLUSION}

Three Saccharomyces cerevisiae strains isolated from Borassus akeassii wines and identified by amplification and RFLP analysis of the 5-8S-ITS region were used for in vitro fermentation of unfermented palm sap.

This work confirmed that the use of active Saccharomyces cerevisiae strains for fermentation of palm sap gave a more quality and hygienic palm wine. Flowing vapor sterilization used during the production of conventional wines, can be used for the improvement of palm wine quality.

Acknowledgement: The authors are grateful the International Foundation for Science (IFS: E/5233-1) and West African Economic and Monetary Union (UEMOA) for their supporting. They would also like to thank UMR1083 Montpellier, France for the helpful technics.

\section{REFERENCES}

ADELEKE, R.O., ABIODUN, O.A. 2010. Physico-chemical Properties of Commercial Local Beverages in Osun State, Nigeria. Pakistan Journal of

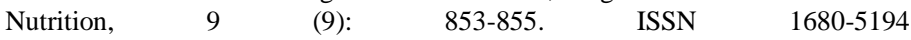
http://dx.doi.org/10.3923/pjn.2010.853-855

AMOA-AWUA, W.K., SAMPSON, E., TANO-DEBRAH, K. 2006. Growth of yeasts, lactic and acetic acid bacteria in palm wine during tapping and fermentation from felled oil palm (Elaeis guineensis) in Ghana. Journal of Applied Microbiology, 102 (2): 599-606. http://dx.doi.org/10.1111/j.13652672.2006.03074.x

BEN THABET, I., FRANCIS, F., DE PAUW, E., BESBES, S., ATTIA, H., DEROANNE, C., BLECKER, C. 2010. Characterization of proteins from data palm sap (Phoenix dactylifera L.) by a proteomic approach. Food Chemistry, 123: 765-770. http://dx.doi.org/10.1016/j.foodchem.2010.05.024

CLEMENT, T., 2012. Utilisation d'un fermenteur continu multi-étagé pour la compréhension des mécanismes d'adaptation de la levure à des ajouts d'azote conditions œnologiques. Thèse, 248 p, Centre International d'études Supérieures en Sciences Agronomiques, Montpellier SupAgro.

ESTEVE-ZARZOSO, B., BELLOCH, C., URUBURU, F., QUEROL, A. 1999 Identification of yeasts by RFLP analysis of the 5.8S rRNA gene and the two ribosomal internal transcribed spacers. Identification of yeasts by RFLP analysis of the 5.8S rRNA gene and the two ribosomal internal transcribed spacers. International Journal of Systematic Bacteriology, 49: 329-337. http://dx.doi.org/10.1099/00207713-49-1-329.

EZERONYE, O.U., LEGRAS, J.L. 2005. Genetic analysis of Saccharomyces cerevisiae strains isolated from palm wine in eastern Nigeria. Comparison with other African strains, Journal of Applied Microbiology, ISSN 1364-5072. http://dx.doi.org/10.1111/j.1365-2672.2008.04118.x.

KUMAR, Y. S., VARAKUMAR, S., REDDY, O.V.S., 2012. Evaluation of antioxidant and sensory properties of mango (Mangifera indica L.) wine. CyTA-
Journal
Food
10:
(1)
$12-20$.

http://dx.doi.org/10.1080/19476337.2010.530693.

NAKNEAN, P., MEENUNE, M., ROUDAUT, G. 2009. Changes in physical and chemical properties during the production of palm sugar syrup by open pan and vacuum evaporator. J. Asian Journal of Food and Agro-Industry, 2: 448-456. http://dx.doi.org/10.1007/s12355-014-0308-3.

NGỌC, N.M., MINH, N. P., DAO, D.T.A. 2014. Different processing conditions affect palm (thot not) wine fermentation. American Journal of Research Communication, 2(1): 143-157.

Norme ISO 7218. 2007. Microbiologie des denrées alimentaires et aliments pour animaux-Règles générales relatives aux analyses microbiologiques. Page 69 .

OBAHIAGBON, F.I., OSAGIE, A.U. 2007. Changes in the physico-chemical characteristics of processed and stored Raphia hookeri palm Sap (Shelf life studies). American Journal of Food Technology, 2: 323-326. http://dx.doi.org/10.3923/ajft.2007.323.326

OKAFOR, N. 1975 a. Preliminary microbiological studies on the preservation of palm wine. Journal of applied Bacteriology, 38: 1-7. http://dx.doi.org/10.1111/j.1365-2672.1975.tb00493.x

OLAWALE, A. K., AKINTOBI, A. O., DAVID, O. M., 2010. Evaluation of microbial quality and alcoholic improvement of natural and fermented Raphia Palm wine ("Ogoro"). New York Science Journal, 3(2).

OPARA, C.C., AJOKU G., MADUMELU, N.O. 2013. Palm Wine mixed culture fermentation kinetics. Greener Journal of Physical sciences ISSN: 2276-7851, 3 (1):028-037.

OUOBA, L .I. I., KANDO, C., PARKOUDA, C., SAWADOGO, L. H., DIAWARA, B., SUTHERLAND, J.P. 2012. The microbiology of Bandji, palm wine of Borassus akeassii from Burkina Faso: identification and genotypic diversity of yeasts, lactic acid and acetic acid bacteria.Journal of Applied Microbiology, ISSN 1364-5072. http://dx.doi.org/10.1111/jam.1

PHAICHAMNAN, M., POSRI, W., MEENUNE, M. 2010. Quality profile of palm sugar concentrate produced in Songkhla province, Thailand. International Food Research Journal, 17: 425-432.

SANTIAGO-URBINA, J. A., RUÍZ-TERÁN, F. 2014. Microbiology and biochemistry of traditional palm wine produced around the world. International Food Research Journal, 21(4): 1261-1269.

STRINGINI, M., COMITINI, F., TACCARI, M., CIANI, M. 2009. Yeas diversity during tapping and fermentation of palm wine from Cameroon. Food Microbiology 26: 415-420. http://dx.doi.org/10.1016/j.fm.2009.02.006

TAPSOBA, F., SAVADOGO, A., SOMDA K.M., ZONGO, C., BARRO, N., TRAORÉ, S.A. 2011. Microbial biodiversity and physico-chemical parameters of some Palmyra (Borassus akeassii) wines traditionally produced in Burkina Faso. Revue de Microbiologie Industrielle, Sanitaire et Environnementale, 5(2):1-22. TAPSOBA, F., SAVADOGO, A., ZONGO, C., TRAORÉ, A.S. 2014. Impact of technological diagram on biochemical and microbiological quality of Borassus akeassii wine produced traditionally in Burkina Faso. American Journal of Food Science and Technology, 2 (6): 179-186. http://dx.doi.org/10.12691/ajfst-2-6-2

YALCIN, S.K., ÖZBA, Z.Y. 2006. Production of glycerol by wine yeasts. Food Technology and Biotechnology, 44 (4) 525-529. http://dx.doi.org/10.1007/s11274-005-2634-9 